\title{
Altering peptide fibrillization by polymer conjugation
}

Article

Accepted Version

Dehn, S., Castelletto, V., Hamley, I. W. and Perrier, S. (2012) Altering peptide fibrillization by polymer conjugation.

Biomacromolecules, 13 (9). pp. 2739-2747. ISSN 1525-7797 doi: https://doi.org/10.1021/bm3007117 Available at https://centaur.reading.ac.uk/29261/

It is advisable to refer to the publisher's version if you intend to cite from the work. See Guidance on citing.

To link to this article DOI: http://dx.doi.org/10.1021/bm3007117

Publisher: American Chemical Society

All outputs in CentAUR are protected by Intellectual Property Rights law, including copyright law. Copyright and IPR is retained by the creators or other copyright holders. Terms and conditions for use of this material are defined in the End User Agreement.

\section{www.reading.ac.uk/centaur}

\section{CentAUR}

Central Archive at the University of Reading

Reading's research outputs online 


\title{
Altering Peptide Fibrillisation by Polymer Conjugation
}

\author{
Sabrina Dehn ${ }^{a}$, Valeria Castelletto ${ }^{b}$, Ian W. Hamley ${ }^{b}$, Sébastien Perrier ${ }^{a, *}$ \\ a Key Centre for Polymers \& Colloids, School of Chemistry, The University of Sydney, NSW, 2006, Australia. Fax: \\ +61 (2) 9351 3329; Tel: +61 (2) 9351 3366; E-mail: sebastien.perrier@sydney.edu.au \\ ${ }^{\mathrm{b}}$ Department of Chemistry, University of Reading, Whiteknights, Reading, RG6 6AD, U.K.
}

A strategy is presented that exploits the ability of synthetic polymers of different nature to disturb the strong self-assembly capabilities of amyloid based $\beta$-sheet forming peptides. Following a convergent approach, the peptides of interest were synthesised via solid-phase peptide synthesis (SPPS) and the polymers via reversible addition-fragmentation chain transfer (RAFT) polymerisation, followed by a copper(I) catalysed azide-alkyne cycloaddition (CUAAC) to generate the desired peptide-polymer conjugates. The particular interest lays in a modified version of the core sequence of the $\beta$-Amyloid peptide $(A \beta), A \beta(16-20)$ (KLVFF). The influence of attaching short poly( $N$-isopropylacrylamide) and poly(hydroxyethylacrylate) to the peptides sequences on the self-assembly properties of the hybrid materials were studied via Infrared Spectroscopy, TEM and circular dichroism. The findings indicate that attaching these polymers disturb the strong self-assembly properties of the biomolecules to a certain degree and allow to influence the aggregation of the peptides based on their $\beta$-sheets forming abilities. This study presents an innovative route towards targeted and controlled assembly of amyloids like fibres to drive the formation of polymeric nanomaterials.

\section{Introduction}

Inspiration from nature and improved synthetic strategies have triggered dramatic advances in the development of multifunctional materials over the past two decades. The combination of biological materials such as proteins and peptides with synthetic polymers is of particular interest since the resultant conjugates benefit from the properties of both components. ${ }^{1}$ These hybrid materials have found many diverse applications, such as tissue engineering ${ }^{2}$, drug delivery ${ }^{3}$ and structured nanomaterials ${ }^{4}$. Nanomaterials in particular benefit greatly from the self-organisation properties of peptides, since they lead to hierarchical nanostructures of much higher complexity than those achievable with synthetic polymers. ${ }^{5}$ For instance, 
nanostructures such as nanofibres ${ }^{6}$ or nanotubes ${ }^{7}$ based on self-assembled polypeptides can be applied in regenerative medicine ${ }^{8}$ or nanoelectronics ${ }^{7}$. Various approaches to design peptide based nanomaterials, how to control and trigger their self-assembly has been described including their use to guide the formation of supramolecular structures and related functionalities. ${ }^{9,} 10$ The challenge has now shifted to the incorporation of additional functional molecules such as polymers for the generation of highly functional nanostructured materials. ${ }^{3,11}$ The self-organisation properties of peptides or proteins can be used to encode structural information in the polymeric nanomaterials at the molecular level. In addition the synthetic polymer part of these nanomaterials can also affect the self-organisation properties of the peptides or proteins thus changing their reactivity. Peptides and proteins are well known to strongly self-assemble into $\beta$-sheets, which can further aggregate into ribbons and fibrils. $^{12}$. Indeed, $\beta$-sheet forming peptides have been intensively discussed in the past decade in the context of protein misfolding diseases ${ }^{13}$, such as Alzheimer's $(A D)^{14}$ and Parkinson's (PD) diseases ${ }^{15}$. In the case of $A D$, the $\beta$-Amyloid peptide $(A \beta)$ is believed to aggregate into fibrils and form amyloids, ${ }^{16,}{ }^{17}$ and several studies suggest that a critical sequence for fibrillisation is $A \beta(16-20)$, KLVFF. $^{5,18}$ It has also recently been shown that addition of two more phenylalanine residues to that core sequence (FFKLVFF) permits even stronger aggregation via hydrophobic and aromatic interactions. ${ }^{19}$ Recent work has focused on attaching synthetic polymers to these $\beta$-sheets forming peptide sequences to investigate the influence on the $\beta$-sheet forming properties. ${ }^{4,20}$ Synthetic strategies for peptide/protein-polymer conjugates are well described, ${ }^{3,11,21,22}$ and the properties of the peptides polymer conjugates have been examined. Pochan et al. used ethylenglycol modified amino acids o synthesise poly'peptides' which retain the $\alpha$-helical structure of the amino acids. ${ }^{23}$ In some cases the self-assembly abilities of the conjugates and corresponding properties such as gel formation can be controlled by the degree of polymerisation and the balance between $\alpha$-helical and $\beta$-sheet structures. ${ }^{24}$ Studies on the influence of conjugated synthetic polymeric chains to $\beta$-sheets forming peptides and their $\beta$ sheets forming properties in particular have been reported as well. ${ }^{4,25-28}$ For instance, Adams et al. have used polyethylene oxide (PEO) with side chain conjugated peptides to form vesicles, ${ }^{29}$ and Tzokova et al. have demonstrated the importance of the nature of the peptide and the relative balance between polymer and peptide for the self-assembly process. ${ }^{30}$ However there are limited precise investigation on the self-assembly properties of the resultant conjugates ${ }^{4,27,31-36}$ and there is still a high demand on understanding this process to exploit the self-assembly properties with full capacity. Poly(ethylene glycol) (PEG) is the most common polymer used in 
research on peptide-polymer conjugates aggregation because it improves biocompatibility and decreases immunoresponse. ${ }^{37}$ To date PEG is the only polymer considered in studies involving the core sequence of the $\beta$-Amyloid peptide (A $\beta 16$ $20),{ }^{20,25,31,38,39}$ and it has been reported that hydrophobically modified $A \beta(16-20)$ sequences (FFKLVFF) form very strong self-assembled structures ${ }^{19}$ which are retained even after PEGylation ${ }^{25}$. These initial results suggest that the nature of the peptide may dictates the suitability of a given conjugate polymer to alter the strong self-assembly properties of the $\beta$-sheet forming peptides. Herein, we describe a systematic investigation on the capability of a polar polymer (poly(hydroxylethyl acrylate), PHEA) and a less polar polymer (poly( $N$-isopropyl acrylamide), PNIPAAM) to influence the self-assembly properties of a $\beta$-sheet forming peptide. A modified $A \beta(16-20)$ sequence with two additional phenylalanine units (FFVLKFF) was used as a model system. In addition, $A \beta(16-19)$ sequence, similarly modified with one phenylalanine units, (FVLKFF) was also investigated to assess the importance of phenylalanine in the peptide sequence. We opted for a convergent approach, in which the peptides and polymers were first synthesised via solid-phase peptide synthesis (SPPS) and reversible addition-fragmentation chain transfer (RAFT) polymerisation respectively, followed by a copper $(\mathrm{I})$ catalysed azide-alkyne cycloaddition (CuAAC) to generate the desired peptide-polymer conjugates (Scheme 1). 
a)

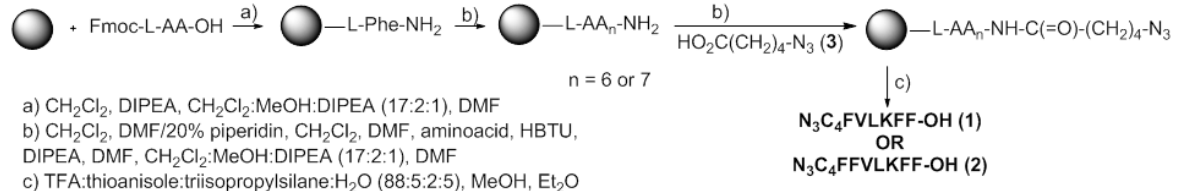
b)

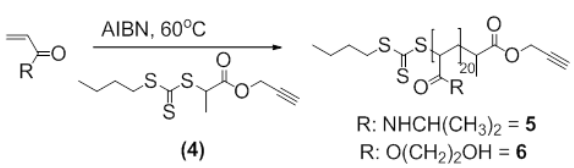

c)

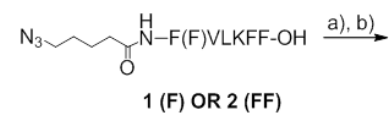

a) $\mathrm{DMF}, \mathrm{CuSO}_{4}$, sodium ascorbate, polymer 5 OR $6, \mu \mathrm{W},, 100^{\circ} \mathrm{C}, 200 \mathrm{~W}, 20 \mathrm{~min}$ b) $\mathrm{DMF}, \mathrm{CuSO}_{4}$, sodium ascorbate, azide-resin, $\mu \mathrm{W}, 80^{\circ} \mathrm{C}, 200 \mathrm{~W}, 20 \mathrm{~min}$

Scheme 1: a) Solid phase supported peptide synthesis of $\mathrm{N}_{3} \mathrm{C}_{4}-\mathrm{FVLKFF-OH}$ (1) and $\mathrm{N}_{3} \mathrm{C}_{4}-\mathrm{FFVLKFF-OH}(2)$; b) RAFT polymerisation to yield PNIPAAM 20 (5) and $\mathrm{PHEA}_{20}$ (6) c) Microwave assisted CuAAC reaction to generate the FFVLKFF conjugates $8\left(\right.$ PNIPAAM $\left._{20}\right)$ and $10\left(\mathrm{PHEA}_{20}\right)$ and the FVLKFF conjugates $7\left(\mathrm{PNIPAAM}_{20}\right)$ and $9\left(\mathrm{PHEA}_{20}\right)$.

\section{Materials and Methods}

Fmoc-Phe-OH, Fmoc-Lys(Boc)-OH, Fmoc-Leu-OH, Fmoc-Val-OH, 2 (1Hbenzotriazole-1-yl)-1,1,3,3-tetramethyluronium (HBTU) were obtained from GL Biochem and used as supplied. Butyl-trithiocarbonate propanoicacid (BTCPA) was obtained from Dulux and used as supplied, and azoisobutyronitrile (AIBN) was obtained from Aldrich and precipitated from methanol prior to use. Hünig's base $N, N$ (Diisopropylethylamine, DIPEA), trifluoroacetic acid (TFA), Thioansiol, Triisopropylsilane, sulfurylchloride, and all solvents were ordered through SigmaAldrich and used as received. $N$-isopropylacrylamide (NIPAaM) was purchased from Sigma-Aldrich and recrystallised before usage. Hydroxyethyl acrylate (HEA) was purchased from Sigma-Aldrich and was deinhibited before polymerisation. All other chemicals were ordered through Sigma-Aldrich and used without any further purification. 
Nuclear Magnetic Resonance (NMR). NMR analyses were carried out on Bruker Ultra Shield Avance Spectrometers (200 or $300 \mathrm{MHz}$ ). For all NMR analyses deuterated solvents as stated were used.

Size Exclusion Chromatography (SEC). SEC analyses were performed at $50^{\circ} \mathrm{C}$ using a Agilent SEC system (PL-GPC50 Plus), equipped with a guard column and two Polar Gel-M columns $(300 \times 7.5 \mathrm{~mm})$ and a PL-RI detector. The system was running at $50^{\circ} \mathrm{C}$ with DMF using $0.1 \mathrm{wt} \% \mathrm{LiBr}, 0.05 \mathrm{~g} / \mathrm{L}$ hydroquinone on a flowrate of $0.7 \mathrm{~mL} / \mathrm{min}$. For sample analysis a poly-Styrene calibration has been used.

Transmission Electron Micrsocopy (TEM). Samples were prepared by placing a drop of sample solution on a carbon coated copper grid covered with thin film of pioloform. Samples were air dried for at least 24 hours before the analysis. TEM images were obtained using a JOEL1400 electron microscope.

Fourier Transform Infra-Red (FT-IR). FT-IR spectra were obtained from a Bruker ISF66v FT-IR from dried film of sample solution. The numbers of scans were set at 32.

Electrospray lonisation Mass Spectroscopy. ESI analysis was performed using a Finnigan LCQ mass spectrometer.

Circular Dichroism Spectroscopy (CD). CD spectra were recorded using a Chirascan spectropolarimeter (Applied Photophysics, UK). Solutions of the peptides and conjugates in methanol were loaded in parallel plaque cells (Hellma quartz Suprasil( ), with a 0.1 or $1 \mathrm{~mm}$ pathlength. The CD data were measured using $1 \mathrm{sec}$ acquisition time per point and $0.5 \mathrm{~nm}$ step. The post-acquisition smoothing tool from Chirascan software was used to remove random noise elements from the averaged spectra. A residual plot was generated for each curve in order to verify whether or not the spectrum has been distorted during the smoothing process. The CD signal from the methanol was subtracted from the CD data of the peptide solutions.

Small-Angle X-ray Scattering (SAXS). Experiments were performed on beamline ID02 at the ESRF, Grenoble, France. Samples, dissolved in methanol, were placed in a glass capillary mounted in a brass block for temperature control. Micropumping was used to minimise beam damage, by displacing a drop of the sample by $0.01-0.1$ $\mathrm{mm}$ for each exposure. The sample-to-detector distance was $1.2 \mathrm{~m}$, and the $\mathrm{x}$-ray energy was $12.46 \mathrm{keV}$. The $q=4 \pi \sin \theta / \lambda$ ( $2 \theta$ is the scattering angle and $\lambda$ is the wavelength) range was calibrated using silver behenate. Data processing (background subtraction, radial averaging) was performed using the software SAXSUtilities. 


\section{General procedure for the synthesis of peptides 1 and 2.}

The azide modified peptides $\mathrm{N}_{3} \mathrm{C}_{4}$-FVLKFF (1) and $\mathrm{N}_{3} \mathrm{C}_{4}-\mathrm{FFVLKFFC}{ }_{4} \mathrm{~N}_{3}$ (2) have been synthesized via standard solid-phase 9-fluorenylmethoxycarbonyl (Fmoc) peptide synthesis on a 2-chlorotrityl resin. $2 \mathrm{~g}\left(1.5 \mathrm{mmol} \mathrm{g}^{-1}\right)$ 2-chlorotrityl resin was suspended in $5 \mathrm{~mL}$ DCM for $30 \mathrm{~min}$. in a fritted syringe $(10 \mathrm{~mL})$. After the solvent has been filtered off, a solution of Fmoc-L-Phenylalanin- $\mathrm{OH}(6.0 \mathrm{mmol}, 2.322 \mathrm{~g})$ and $\mathrm{N}, \mathrm{N}$ Diisopropylethylamine (DIPEA, Hünig's Base) (12 mmol, $3.08 \mathrm{~g})$ in DMF (5 mL) was added and shaken for $2 \mathrm{~h}$. The solvent was filtered off and the resin was washed with DCM : MeOH : DIPEA $17: 2: 1(3 \times 10 \mathrm{~mL})$ to cap any unreacted peptide chains. After washing the resin with DCM $(3 \times 10 \mathrm{~mL})$, DMF $(3 \times 10 \mathrm{~mL})$ and DCM $(3 \times 10 \mathrm{~mL})$ it was dried in vacuum to be used for further SPPS. UV-Vis was used to determine a loading of $1.06 \mathrm{mmol}$ Fmoc-L-Phenylalanin-OH per gramm resin. $0.5 \mathrm{~g}$ of the resin was used for further SPPS. For coupling of each Fmoc-protected L-amino acid, the resin was swollen in $5 \mathrm{~mL}$ DCM for $30 \mathrm{~min}$. and deprotected with $20 \%$ solution piperidin in DMF $(2 \times 5 \mathrm{~mL})$ for 3 min. After washing the resin with DMF $(3 \times 10 \mathrm{~mL})$, $\operatorname{DCM}(3 \times 10 \mathrm{~mL})$ and DMF $(3 \times 10 \mathrm{~mL})$ a solution of Fmoc-L-amino acid-OH (1.5 eq.), HBTU (2 eq.) to activate the N-terminus and DIPEA (5 eq.) in DMF ( $5 \mathrm{~mL}$ ) was added and shacked over night $(16 \mathrm{~h})$. The solvent has been filtered off and the resin washed with DMF $(5 \times 10 \mathrm{~mL})$ and unreacted chains capped with $\mathrm{DCM}: \mathrm{MeOH}$ : DIPEA $17: 2: 1(3 \times 10 \mathrm{~mL})$ for $2 \times 3$ min. After washing with DMF $(5 \times 10 \mathrm{~mL})$ the next coupling step was performed. Upon addition of the last amino acid, the azide linker $\mathrm{C}_{4} \mathrm{~N}_{3} 3$ which was synthesised according to previous work by our group (Hamilton ChemComm) was couple under the same reaction conditions. A mixture of TFA : Thioanisol : Triisopropylsilane : $\mathrm{H}_{2} \mathrm{O}=88: 5: 2: 5$ (10 $\mathrm{mL}$ for $3 \mathrm{~h}$ ) was used to isolate the desired peptide sequences 1 and 2 from the solid phase. The obtained solution was concentrated to near dryness, dissolved in a small amount of $\mathrm{MeOH}$ and precipitated from ice-cold $\mathrm{Et}_{2} \mathrm{O}$. If necessary, preparative $\mathrm{HPLC}\left(\mathrm{ACN}, \mathrm{H}_{2} \mathrm{O}\right.$, TFA) was performed for purification. Drying in vacuum yielded the opaque solids 1 and $2(0.127 \mathrm{~g}, 41 \%)$.

Analysis of 1 :

${ }^{1} \mathrm{H}-\mathrm{NMR}(\mathrm{d}-\mathrm{TFA}, 300 \mathrm{MHz}) \delta=7.223-7.393(\mathrm{~m}, 15 \mathrm{H}, \mathrm{Har}), 6.860\left(\mathrm{~s}, \mathrm{br}, \mathrm{NH}, \mathrm{NH}_{2}\right.$ ), 4.994-5.060 (d, 3H, $19.8 \mathrm{~Hz}, \mathrm{CHNHbackbone),} \mathrm{4.668-4.745} \mathrm{(d,} \mathrm{J} \mathrm{=} \mathrm{23.1Hz,} 2 \mathrm{H}$, CHNHbackbone), 4.467 (s, br, $1 \mathrm{H}, \mathrm{CHNHbackbone),} 3.442$ (s, br, $2 \mathrm{H}, \mathrm{CH}_{2} \mathrm{~N}_{3}$ ), 3.176 3.324 (d, br, J = 44.4 Hz, 6H, CH$H_{2} \mathrm{Phe}$ ), 2.597 (s, br, $2 \mathrm{H}, \mathrm{CH}_{2} \mathrm{NH}_{2}$ ), 2.144-2.212 (m, 
$\left.3 \mathrm{H}, \mathrm{COCH}_{2}, \mathrm{CH}\left(\mathrm{CH}_{3}\right)_{2} \mathrm{CH}\right), 1.379-2.024\left(\mathrm{~m}, \mathrm{br}, 13 \mathrm{H}, \mathrm{CH}_{2} \mathrm{CH}_{2} \mathrm{~N}_{3}, \mathrm{CH}_{2} \mathrm{CH}_{2} \mathrm{CH}_{2} \mathrm{~N}_{3}\right.$, $\left.\mathrm{CH}_{2} \mathrm{CH}_{2} \mathrm{CH}_{2} \mathrm{NH}_{2}, \quad \mathrm{CH}_{2} \mathrm{CH}_{2} \mathrm{NH}_{2}, \quad \mathrm{CH}_{2}\left(\mathrm{CH}_{2}\right)_{3} \mathrm{NH}_{2}, \quad \mathrm{CH}_{2}\left(\mathrm{CH}\left(\mathrm{CH}_{3}\right)_{2}\right), \quad \mathrm{CH}\left(\mathrm{CH}_{3}\right)_{2} \mathrm{CH}_{2}\right)$, 1.056-1.119 ( $\mathrm{m}, \mathrm{br}, 12 \mathrm{H}, \mathrm{CH}_{3}$ peptide side chains) ppm.

${ }^{13} \mathrm{C}-\mathrm{NMR}$ (d-TFA, 400MHz) $\delta=178$ (COOH), 177 (NHCO-), 175 (NHCO-), 136 (Car$\mathrm{CH}_{2}$ ), 131 (Car, Car- $\mathrm{CH}_{2}$ ), 129 (Car- $\mathrm{CH}_{2}$ ), 120 (Car), 118 (Car), 116 (Car), 113 (Car), 19.5-62.5 $\left(\mathrm{CH}_{3}, \mathrm{CH}_{2}, \mathrm{CH}, 24 \mathrm{C}\right) \mathrm{ppm}$. MS $\left(\mathrm{ESI}^{+}\right) \mathrm{m} / \mathrm{z}=925.25\left(\mathrm{M}+\mathrm{H}^{+}, 100\right)$. IR (ATR FT-IR) v = $3282(\mathrm{~m}, \mathrm{NH}-\mathrm{H}), 2153\left(\mathrm{w}, \mathrm{N}_{3}\right), 1679$ (s, C=O, amide I), 1631 (m, C=O, amide I) $\mathrm{cm}^{-1}$. HighRes MS: found $=1072.59785\left(\mathrm{M}+\mathrm{H}^{+}\right)$, calculated $=1071.59$.

Analysis of 2:

${ }^{1} \mathrm{H}-\mathrm{NMR}(\mathrm{d}-\mathrm{TFA}, 300 \mathrm{MHz}) \delta=7.143-7.280(\mathrm{~m}, 20 \mathrm{H}, \mathrm{Har}), 6.775\left(\mathrm{~s}, \mathrm{br}, \mathrm{NH}, \mathrm{NH}_{2}\right)$, 4.933-4.977 (d, J = 13.2 Hz, 4H, CHNHbackbone), 4.574-4.666 (d, J = 27.6 Hz, 2H, CHNHbackbone), 4.322 (s, br, $1 \mathrm{H}, \mathrm{CHNHbackbone),} \mathrm{3.077-3.359} \mathrm{(m,} 10 \mathrm{H}, \mathrm{CH}_{2} \mathrm{~N}_{3}$, 14, $\mathrm{CH}_{2} \mathrm{Phe}$ ), 2.490 (s, br, $2 \mathrm{H}, \mathrm{CH}_{2} \mathrm{NH}_{2}$ ), 1.441-1.837 (m, $16 \mathrm{H}, \mathrm{CH}, \mathrm{CH}_{2}$ ), 0.862$1.031\left(\mathrm{~m}, 12 \mathrm{H}, \mathrm{CH}_{3}\right.$ peptide side chains) ppm. ${ }^{13} \mathrm{C}-\mathrm{NMR}(\mathrm{d}-\mathrm{TFA}, 300 \mathrm{MHz}) \delta=181.05$ (COOH), 178.54 (NHCO-), 176.12 (NHCO-), 175.43 (NHCO-), 175.12 (NHCO-), $136.57\left(\mathrm{Car}-\mathrm{CH}_{2}\right), 131.20$ (Car, Car- $\left.\mathrm{CH}_{2}\right), 129.92\left(\mathrm{Car}^{-} \mathrm{CH}_{2}\right), 120.15$ (Car), 118.62 (Car), 115.07 (Car), 112.36 (Car), 18-62.27 $\left(\mathrm{CH}_{3}, \mathrm{CH}_{2}, \mathrm{CH}, 26 \mathrm{C}\right) \mathrm{ppm} . \mathrm{MS}\left(\mathrm{ESI}^{+}\right) \mathrm{m} / \mathrm{z}$

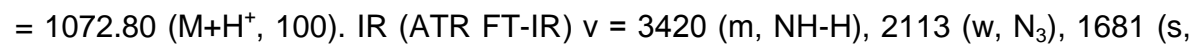
$\mathrm{C}=\mathrm{O}$, amide I), $1629(\mathrm{~m}, \mathrm{C}=\mathrm{O}$, amide $\mathrm{I}) \mathrm{cm}^{-1}$. HighRes MS: found $=925.52944$ $\left(\mathrm{M}+\mathrm{H}^{+}\right)$, calculated $=924.52$.

\section{Synthesis of 5-azido pentanoic acid 3.}

The synthesis of the $\mathrm{C}_{4} \mathrm{~N}_{3}$ linker is followed a procedure from Srinivasan ${ }^{40}$ and Kakwere $^{33}$. Under inert conditions, bromovaleric acid $(40 \mathrm{mmol}, 7.24 \mathrm{~g})$ was dissolved in $8 \mathrm{~mL} \mathrm{MeOH}$ and cooled down to $0^{\circ} \mathrm{C}$. Thionylchloride $(120 \mathrm{mmol}, 14.27$ g) has be added dropwise under $\mathrm{N}_{2}$ atmosphere within $45 \mathrm{~min}$. and stirred for $30 \mathrm{~min}$. at $0^{\circ} \mathrm{C}$. The reaction mixture was allowed to warm up to room temperature and was stirred for $19 \mathrm{~h}$. After solvent evaporation, the residue was suspended in $50 \mathrm{~mL}$ ethylacetate and extracted with $\mathrm{NaHCO}_{3}(3 \times 30 \mathrm{~mL}), \mathrm{H}_{2} \mathrm{O}(3 \times 30 \mathrm{~mL})$ and brine $(1 \times$ $30 \mathrm{~mL}$ ). Drying over $\mathrm{NaSO}_{4}$ and removing the solvent under reduced pressure lead to a brown liquid.

Upon addition of $30 \mathrm{~mL}$ DMSO, $\mathrm{NaN}_{3}(77 \mathrm{mmol}, 5 \mathrm{~g})$ was added under rapid stirring. This solution has been stirred at $50^{\circ} \mathrm{C}$ for $24 \mathrm{~h}$ and the resultant white suspension 
has been taken up with $20 \mathrm{~mL} \mathrm{H}_{2} \mathrm{O}$ and was extracted with $\mathrm{Et}_{2} \mathrm{O}(4 \times 40 \mathrm{~mL}$ ). Washing with brine, drying over $\mathrm{NaSO}_{4}$ and removing the solvent under reduced pressure yield in a brown oil. After dissolving in $30 \mathrm{~mL}$ THF : $\mathrm{H}_{2} \mathrm{O}=3: 1(\mathrm{v}: \mathrm{v}), 20$ $\mathrm{mL}$ aqueous $\mathrm{LiOH}(73 \mathrm{mmol}$ ) was added and the mixture was stirred for $4 \mathrm{~h}$ at room temperature. THF was removed under reduced pressure and the aqueous phase was combined with $50 \mathrm{~mL}$ ethylacetate. Washing with $1 \mathrm{~N} \mathrm{HCl}(3 \times 50 \mathrm{~mL}), \mathrm{H}_{2} \mathrm{O}(3 \times$ $50 \mathrm{~mL})$ and brine $(2 \times 50 \mathrm{~mL})$ and drying the combined organic phases over $\mathrm{NaSO}_{4}$

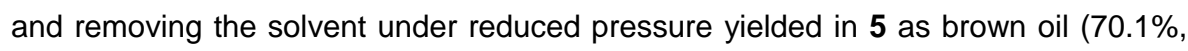
$4.01 \mathrm{~g})$.

${ }^{1} \mathrm{H}-\mathrm{NMR}\left(\mathrm{CDCl}_{3}, 300 \mathrm{MHz}\right) \delta=11.442(\mathrm{~s}, 1 \mathrm{H}, \mathrm{OH}), 3.233-3.276(\mathrm{t}, \mathrm{J}=12.9 \mathrm{MHz}$, 6.6MHz, $\left.2 \mathrm{H}, \mathrm{CH}_{2} \mathrm{~N}_{3}\right), 2.328-2.375\left(\mathrm{t}, \mathrm{J}=14.1 \mathrm{MHz}, 6.9 \mathrm{MHz}, 2 \mathrm{H}, \mathrm{CH}_{2}\left(\mathrm{CH}_{2}\right)_{3} \mathrm{~N}_{3}\right), 1.547-$ $1.726\left(\mathrm{~m}, 4 \mathrm{H}, \mathrm{CH}_{2} \mathrm{CH}_{2} \mathrm{~N}_{3}\right)$ ppm. ${ }^{1} \mathrm{H}-\mathrm{NMR}$ data are in agreement with literature results. $^{33}$

\section{Synthesis of (prop-2-ynyl propanoate)yl butyltrithiocarbonate (PPBTC, 4):}

The alkyne modified RAFT agent PPBTC 4 was synthesised as described by Konkolewicz et al. ${ }^{41}$ Butyltrithiocarbonate propanoic acid (BTCPA) (2.06 g, 8.60 $\mathrm{mmol}$ ) was dissolved in $50 \mathrm{~mL}$ DCM and cooled down to $0^{\circ} \mathrm{C}$. Propargyl acohol $(2.42$ $\mathrm{g}, 23.02 \mathrm{mmol}), \operatorname{EDCl}(3.02 \mathrm{~g}, 12.62 \mathrm{mmol})$ and DMAP $(0.13 \mathrm{~g}, 1.1 \mathrm{mmol})$ was added and stirred at $0^{\circ} \mathrm{C}$ for $2 \mathrm{~h}$. The reaction mixture was allowed to warm up to room temperature and was stirred for additional $16 \mathrm{~h}$. Washing with $\mathrm{H}_{2} \mathrm{O}(5 \times 20 \mathrm{~mL})$, drying over $\mathrm{MgSO}_{4}$ and removing the solvents yielded to a yellow oil. Purification was achieved via passing over a silica pad using toluene : ethylacetate $9: 1$. Removing solvents and drying in vacuum gave the desired product 4 as yellow oil $(91.7 \%, 2.16$ g). ${ }^{1} \mathrm{H}-\mathrm{NMR}\left(\mathrm{CDCl}_{3}, 300 \mathrm{MHz}\right) \delta=4.802-4.876\left(\mathrm{q}, \mathrm{J}=7.5 \mathrm{~Hz}, 1 \mathrm{H}, \mathrm{SCHCH}_{3} \mathrm{CO}\right), 4.726$ (t, J = 1.2 Hz, 2H, CH $2 \mathrm{CCH}$ ), 3.30-3.379 (t, J = 7.2 Hz, 2H, $\mathrm{CH}_{3}\left(\mathrm{CH}_{2}\right)_{2} \mathrm{CH}_{2} \mathrm{~S}-$ ), 2.4822.498 (t, J = 2.4 Hz, $\left.1 \mathrm{H}, \mathrm{CH}_{2} \mathrm{CCH}\right), 1.595-1.725\left(\mathrm{~m}, 5 \mathrm{H}, \mathrm{CH}_{3} \mathrm{CH}_{2} \mathrm{CH}_{2} \mathrm{CH}_{2} \mathrm{~S}-\right.$, $\mathrm{SCHCH}{ }_{3} \mathrm{CO}$ ), 1.385-1.484 (m, $\left.2 \mathrm{H}, \mathrm{CH}_{3} \mathrm{CH}_{2}\left(\mathrm{CH}_{2}\right)_{2} \mathrm{~S}-\right), 0.901-0.949$ (t, J = 7.2 Hz, 3H, $\left.\mathrm{CH}_{3}\left(\mathrm{CH}_{2}\right)_{3} \mathrm{~S}-\right)$. Data are in agreement with results previously reported by Konkolewicz et al. ${ }^{41}$

\section{General procedure for the synthesis of polymers.}

The RAFT agent 4 was prepared according previously reported by our group ${ }^{34,41,42}$. A mixture of monomer, removed from inhibitors, AIBN (AIBN : RAFT $=0.1: 1$ eq.) 
and solvents were added. The reaction vessel has been purged with $\mathrm{N}_{2}$ for 15 min. and left under a nitrogen atmosphere of 1 atm for the polymerisation. $\mathrm{N}$ isopropylacrylamide polymerisation was performed in dioxane at $60^{\circ} \mathrm{C}$, Hydroxyethayl acrylate in tert-butanol at $70^{\circ} \mathrm{C}$ and purified via precipitation from icecold hexane : $\mathrm{Et}_{2} \mathrm{O}(4: 1)$ or $\mathrm{Et}_{2} \mathrm{O}$. The molecular weight of the polymers have been characterised by NMR and SEC.

\begin{tabular}{lccccccc}
\hline & Polymer & [M]: [RAFT] & Time $/ \mathbf{h}$ & Conversion $^{\mathbf{a}}$ & DP $^{\mathbf{a}}$ & $\boldsymbol{M}_{\mathbf{n}}^{\mathbf{b}}$ & $\boldsymbol{\Xi}^{\mathbf{b}}$ \\
\hline $\mathbf{5}$ & PNIPAAM $_{20}$ & $33: 1$ & 4 & $81 \%$ & 20 & 2540 & 5400 \\
$\mathbf{6}$ & PHEA $_{20}$ & $33: 1$ & 3 & 88 & 23 & 2950 & 4600 \\
\hline
\end{tabular}

Table 1: Synthetic details and characterisation for polymers. ${ }^{a}$ : Determined via ${ }^{1} \mathrm{H}-\mathrm{NMR}$ spectroscopy. ${ }^{\mathrm{b}}$ : Determined via SEC. SEC results uncorrected relative to PS standards.

Analysis of 5 :

${ }^{1} \mathrm{H}-\mathrm{NMR}$ (d-TFA, 300MHz) $\delta=4.805$ (s, 2H, $\left.\mathrm{CH}_{2},-\mathrm{O}-\mathrm{CH}_{2}-\mathrm{CCH}\right), 4.142$ (s, 22H, CH, $\left.-\mathrm{NH}-\mathrm{CH}\left(\mathrm{CH}_{3}\right)_{2}\right), 3.460$ (s, $\left.2 \mathrm{H}, \mathrm{CH}_{2}, \mathrm{CH}_{3}-\left(\mathrm{CH}_{2}\right)_{2}-\mathrm{CH}_{2}-\mathrm{S}-\right)$, 2.533, 2.378, 1.934, 1.769, 1.290-1.406 (polymer backbone, $\mathrm{CH}_{3}-\mathrm{CH}_{2}-\mathrm{CH}_{2}-\mathrm{CH}_{2}-\mathrm{S}$-, -O- $\mathrm{CH}_{2}-\mathrm{CCH}$ ), 0.856-0.987 (m, $5 \mathrm{H}, \mathrm{CH}_{2}, \mathrm{CH}_{3}-\mathrm{CH}_{2}-\left(\mathrm{CH}_{2}\right)_{2}-\mathrm{S}-, \mathrm{CH}_{3}, \mathrm{CH}_{3}-\left(\mathrm{CH}_{2}\right)_{3}-\mathrm{S}-$ ) ppm.

Analysis of 6 :

${ }^{1} \mathrm{H}-\mathrm{NMR}\left(\mathrm{d}_{6}-\mathrm{DMSO}, 300 \mathrm{MHz}\right) \delta=4.769(\mathrm{~s}, 23 \mathrm{H}, \mathrm{OH}), 4.675\left(\mathrm{~s}, 1 \mathrm{H},-\mathrm{O}-\mathrm{CH}_{2}-\mathrm{CCH}\right)$, 4.008 (s, $\left.41 \mathrm{H},-\mathrm{O}-\mathrm{CH}_{2}-\mathrm{CH}_{2}-\mathrm{OH}\right), 3.553$ (s, 46H, $\left.-\mathrm{O}-\mathrm{CH}_{2}-\mathrm{CH}_{2}-\mathrm{OH}\right), 3.402$ (s, 2H, $\mathrm{CH}_{3}-$ $\left(\mathrm{CH}_{2}\right)_{2}-\mathrm{CH}_{2}-\mathrm{S}-$ ), $1.066-2.335$ (m, polymer backbone, $\mathrm{CH}_{3}-\mathrm{CH}_{2}-\mathrm{CH}_{2}-\mathrm{CH}_{2}-\mathrm{S}-, \mathrm{CH}_{3}-$ $\left.\mathrm{CH}_{2}-\mathrm{CH}_{2}-\mathrm{CH}_{2}-\mathrm{S}-\right)$, 0.863-0.901 (t, 3H, $\left.\mathrm{CH}_{3}-\left(\mathrm{CH}_{2}\right)_{3}-\mathrm{S}-\right)$ ppm.

General procedure for the synthesis of peptide-polymer conjugates 7, 8, 9, 10.

The azide peptide sequences 1 and $\mathbf{2}$ were combined with the correspondent alkyne polymers 5 and $6, \mathrm{CuSO}_{4}{ }^{*} 5 \mathrm{H}_{2} \mathrm{O}$, Sodiumascorbate and $5 \mathrm{~mL}$ DMF. After vortex mixing, the reaction was carried out in a microwave reactor at $100^{\circ} \mathrm{C}, 200 \mathrm{~W}$, for 15 min. under continuous stirring and $\mathrm{N}_{2}$ cooling. 


\begin{tabular}{|c|c|c|c|c|c|c|c|}
\hline & \multicolumn{6}{|c|}{ Molar equivalents } & \multirow{2}{*}{$\begin{array}{c}\mathrm{mL} \\
\mathrm{DMF}\end{array}$} \\
\hline & polymer & & Azide peptide & & $\mathrm{CuSO}_{4}{ }^{*} 5 \mathrm{H}_{2} \mathrm{O}$ & Sodium & \\
\hline 7 & PNIPAAM $_{20}$ & 1.2 & $\mathrm{~N}_{3} \mathrm{C}_{4}-\mathrm{FVLKFF}$ & 1 & 2 & 10 & 5 \\
\hline 8 & PNIPAAM $_{20}$ & 1.2 & $\mathrm{~N}_{3} \mathrm{C}_{4}$-FFVLKFF & 1 & 2 & 10 & 5 \\
\hline 9 & $\mathrm{PHEA}_{20}$ & 1.2 & $\mathrm{~N}_{3} \mathrm{C}_{4}$-FVLKFF & 1 & 2 & 10 & 5 \\
\hline 10 & $\mathrm{PHEA}_{20}$ & 1.2 & $\mathrm{~N}_{3} \mathrm{C}_{4}$-FFVLKFF & 1 & 2 & 10 & 5 \\
\hline
\end{tabular}

Table 2: Microwave assisted Click reaction between azide peptide and alkyne polymers.

All four peptide polymer conjugates were purified by a second microwave assisted click reaction at $80^{\circ} \mathrm{C}$ using an azide resin to remove any unreacted polymers. The azide resin was synthesised according to procedure previously used in this group. ${ }^{34}$ Excess of copper was removed via filtration through neutral alumina. The solvent was evaporated under reduced pressure; the resultant brown residue was washed with $\mathrm{H}_{2} \mathrm{O}$ to remove any remains of sodiumascorbate. After centrifugation and drying in vacuum a brown solid could be isolated (64 $\mathrm{mg}, 43 \%$ ).

The conjugates have been characterised using ${ }^{1} \mathrm{H}-\mathrm{NMR}$. The disappearance of the peak for the alkyne proton at and the methylgroup next to the triple bond indicated a complete reaction of the alkyne polymer In addition ESI-MS has been used but none of the starting materials were detected, meaning peptide and polymer have been completely consumed by the Click reaction. Furthermore the FT-IR spectra do not show any peaks correspondent to the azide, concluding that all azide has been completely reacted in the Click reaction.

Analysis of 7 .

${ }^{1} \mathrm{H}$-NMR (d-TFA, 300MHz) $\delta=8.587(\mathrm{~s}, 1 \mathrm{H}, \mathrm{CC} H$ triazole), 7.257-7.395 (d, br, $15 \mathrm{H}$, Har), 5.599 (s, 2H, OCH $H_{2}$ Ctriazole), 4.758-5.095 (m, 10H, OH polymer, CHNHbackbone, NH), 0.974-4.502 (PNIPAAM backbone, RAFT side chain, Peptide side chains) ppm.

Analysis of 8. 
${ }^{1} \mathrm{H}-\mathrm{NMR}(\mathrm{d}-\mathrm{TFA}, 300 \mathrm{MHz}) \delta=8.385$ (s, 1H, CCHtriazole), 7.347 (s, br, 20H, Har), 5.234 (s, 2H, OCH$H_{2}$ Ctriazole), 1.045-4.993 ( $\mathrm{CHNHbackbone,} \mathrm{PNIPAAM} \mathrm{backbone,}$ RAFT side chain, Peptide side chains) ppm.

Analysis of 9 .

${ }^{1} \mathrm{H}-\mathrm{NMR}(\mathrm{d}-\mathrm{TFA}, 300 \mathrm{MHz}) \delta=8.902(\mathrm{~s}, 1 \mathrm{H}, \mathrm{CCH}$ triazole), 7.646-7.778 (d, br, 15H, Har), 5.976 (s, 2H, OCH$H_{2}$ Ctriazole), 1.046-5.203 (CHNHbackbone, PNIPAAM backbone, RAFT side chain, Peptide side chains) ppm.

Analysis of 10.

${ }^{1} \mathrm{H}-\mathrm{NMR}(\mathrm{d}-\mathrm{TFA}, 300 \mathrm{MHz}) \delta=8.614-8.690(\mathrm{~d}, \mathrm{br}, 1 \mathrm{H}, \mathrm{CCH}$ triazole), 7.341-7.486 (d, br, 20H, Har), 5.683 (s, 2H, OCH $H_{2}$ Ctriazole), 0.501-5.131 (CHNHbackbone, PNIPAAM backbone, RAFT side chain, Peptide side chains) ppm.

\section{Results and Discussion}

The azide and alkyne functionalities were introduced in the peptide and polymer segment, respectively, following procedures previously published by our group. ${ }^{43}$ Azide-modified FVLKFF (1) and FFVLKFF (2) were synthesised via solid-phase peptide synthesis (SPPS) and the azide group was introduced at the $\mathrm{N}$ terminal. The polymers were synthesised via reversible addition-fragmentation chain transfer (RAFT) polymerisation. The synthesis of the azide modified peptides $\mathbf{1}$ and $\mathbf{2}$ via SPPS leads to white solids in $41 \%$ yield (scheme 1a). Nuclear Magnetic Resonance Spectroscopy (NMR), Electro Spray Ionisiation Mass Spectrometry (ESI-MS), High Resolution Mass Spectrometry (High Res MS), Fourier Transformation Infrared Spectroscopy (FT-IR) (SI, fig. 1-4).Polymerisation of hydroxyethyl acrylate and $N$ isopropyl acrylamide via reversible addition-fragmentation chain transfer (RAFT) polymerisation ${ }^{44-46}$ using chain transfer agent (CTA) 4 gave the functional polymers PHEA $_{20} 5$ and PNIPAAM 206 (scheme 1b) with low polydispersities of 1.1 and 1.2, respectively (SI, fig. 5) and were verified via ${ }^{1} \mathrm{H}(\mathrm{NMR})$ (SI, fig. 6). The desired peptide-polymer conjugates $\mathbf{7}, \mathbf{8}, \mathbf{9}$ and $\mathbf{1 0}$ were synthesised via a convergent approach $^{42,47}$ using microwave assisted copper-catalysed azide-alkyne cycloaddition (CuAAC) (scheme 1c). Successful cycloaddition reaction was confirmed via $1 \mathrm{H}$ NMR (fig. 1a; SI, fig. 7-8), FTIR (fig. 1b) and SEC (SI, fig. 9). 


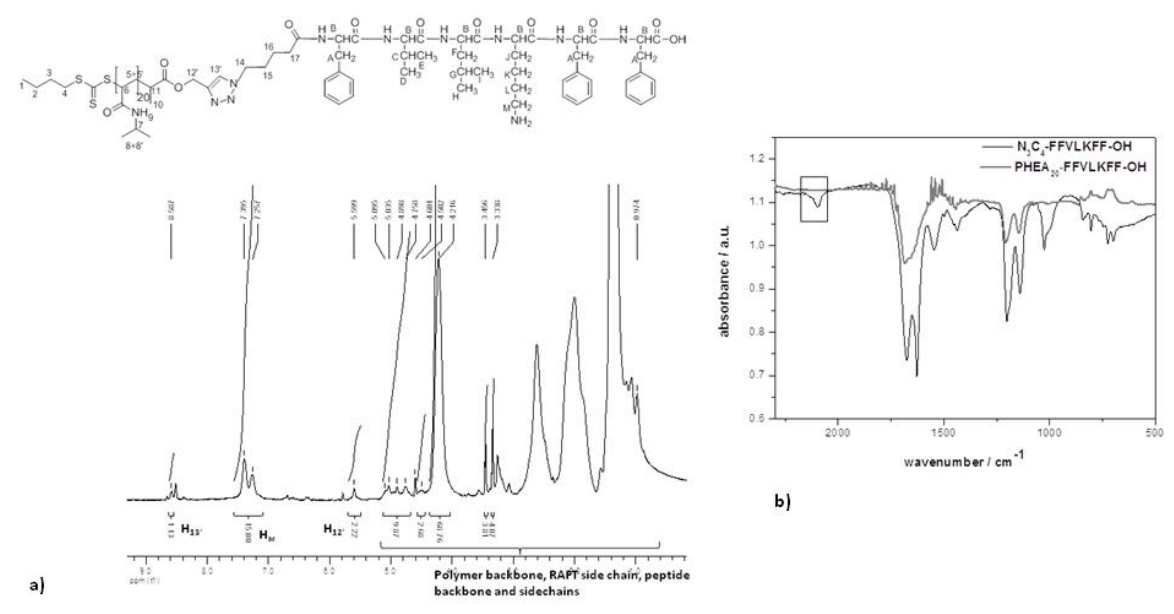

Figure 14: a) ${ }^{1} \mathrm{H}$ NMR spectrum of PNIPAAM 20 -FVLKFF conjugate 7 confirming the successful click reaction. b) FT-IR spectrum from dried films of $1 \mathrm{wt} \%$ methanol solutions of $\mathrm{PHEA}_{20}$-FFVLKFF conjugate 10, showing the disappearance of the azide peak at $2153 \mathrm{~cm}^{-1}$ (black box) as a result of the successful click reaction.

The ${ }^{1} \mathrm{H}$ NMR spectrum (fig. 1a) of PNIPAAM ${ }_{20}$-FVLKFF conjugate 7 reveals the characteristic peak for the proton $\left.\left(\mathrm{H}_{13}\right)^{\prime}\right)$ at the newly triazole ring formed during the CuAAC at $8.587 \mathrm{ppm}$. The proton next to the ester functionality $(\mathrm{H} 12)$ has been shifted down field from $4.805 \mathrm{ppm}$ to $5.590 \mathrm{ppm}\left(\mathrm{H} 12^{\prime}\right)$ which confirms the successful coupling reaction. The disappearance of the azide band at $2153 \mathrm{~cm}^{-1}$ in the FT-IR spectrum (fig. 1b) of PHEA 20 -FFVLKFF conjugate 10 verifies a successful conjugate formation. A shift of the SEC traces for PNIPAAM 20 and $\mathrm{PHEA}_{20}$ indicates the successful coupling between the azide and alkyne. The SEC traces of the PNIPAAM conjugates $\mathbf{7}$ and 8 ( $\mathrm{SI}$, fig. 9) are shifted towards a longer retention time which indicates a higher hydrodynamic volume compared to the pure PNIPAAM 20 . For both PHEA $_{20}$ conjugates $\mathbf{9}$ and $\mathbf{1 0}$ the SEC traces are shifted to shorter retention times due to a lower hydrodynamic volume of the conjugates compared to the pure $\mathrm{PHEA}_{20}$ (SI, fig. 9b).

\section{Self-assembly studies}

The self-assembly properties of peptides $\mathbf{1}$ and $\mathbf{2}$ and of the correspondent PNIPAAM $_{20}$ and PHEA 20 conjugates 7, 8, 9 and $\mathbf{1 0}$ have been studied in $1 \mathrm{wt} \%$ methanol solutions or as the related dried films of $1 \mathrm{wt} \%$ or $5 \mathrm{wt} \%$ methanol solutions. FT-IR spectroscopy of dried films (1 wt \% solutions in methanol) of $\mathbf{1}$ and $\mathbf{2}$ all show the characteristic bands for $\beta$-sheet assemblies at around $1631 \mathrm{~cm}^{-1}$ (parallel $\beta$ sheets) and $1679 \mathrm{~cm}^{-1}$ (antiparallel $\beta$-sheets) ${ }^{48}$ indicating that the additional azide $\mathrm{C}_{4^{-}}$ 
linker does not disturb the ability to form $\beta$-sheet assemblies (fig. 2a). Circular dichroism (CD) spectra of peptides 1 and 2 also reveal characteristic $\beta$-sheet features ${ }^{49}$. A negative band around $230 \mathrm{~nm}$ and a positive band at $218 \mathrm{~nm}$ is observed for 1 and a negative band at $230 \mathrm{~nm}$ and a positive band at $220 \mathrm{~nm}$ for 2 (fig. 2b).

a)

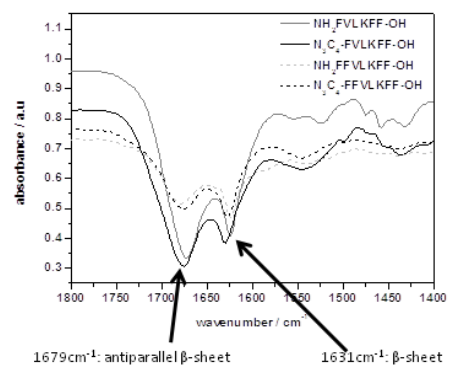

b)

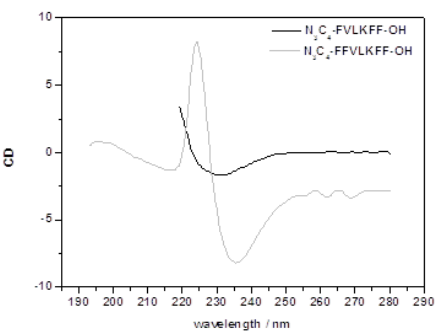

Figure 2: a) FT-IR spectrum of amino peptides and correspondent azide modified peptides 1 and 2 displaying the characteristic bands for $\beta$-sheets around $1679 \mathrm{~cm}^{-1}$ and $1631 \mathrm{~cm}^{-1}$. B) Circular dichroism spectrum of azide peptides 1 and 2 showing the characteristic negative and positive bands for $\beta$-sheet structures.

The classical $\beta$-sheet circular dichroism spectrum has a minimum at $216-220 \mathrm{~nm} .^{5,50}$ The red-shift for this minimum to $230 \mathrm{~nm}$ and $235 \mathrm{~nm}$ respectively is due to the formation of $\mathrm{J}$-aggregates from a head-to-tail stacking of the aromatic units ${ }^{51}$ and is a known feature for fibre formation ${ }^{49}$. These findings imply the presence of $\beta$-sheet structures in both azide peptides 1 and 2. A strong band at $225 \mathrm{~nm}$ observed for $\mathbf{2}$, which results from the fourth phenylalanine residue, shows the influence of these additional $\pi-\pi$ stacking on the secondary structure of the peptide. Measurements using different concentrations display a concentration dependency of the formation of $\beta$-sheet structures. At low concentration (0.16 wt\%) only a weak band around $230 \mathrm{~nm}$ could be observed, but upon increasing the concentration to $0.63 \mathrm{wt} \%$ and $0.9 \mathrm{wt} \%$ clear features for $\beta$-sheet structures could be obtained (SI, fig. 10). That confirms that the addition of the azide linker does not distroy the $\beta$-sheet forming abilities.

TEM and SEM images were obtained from dried films of $1 \mathrm{wt} \%$ methanol solutions on carbon coated copper TEM grids. One of the advantages of applying CuAAC to generate the desired conjugates is no additional staining of the TEM samples is required. ${ }^{42}$ The azide peptides 1 and 2 clearly show strong entangled networks (fig. 3) which points out the strong ability of $\mathbf{1}$ and $\mathbf{2}$ to not only form $\beta$-sheet assemblies, as supported by FT-IR and CD data, but also to aggregate in larger structures. 

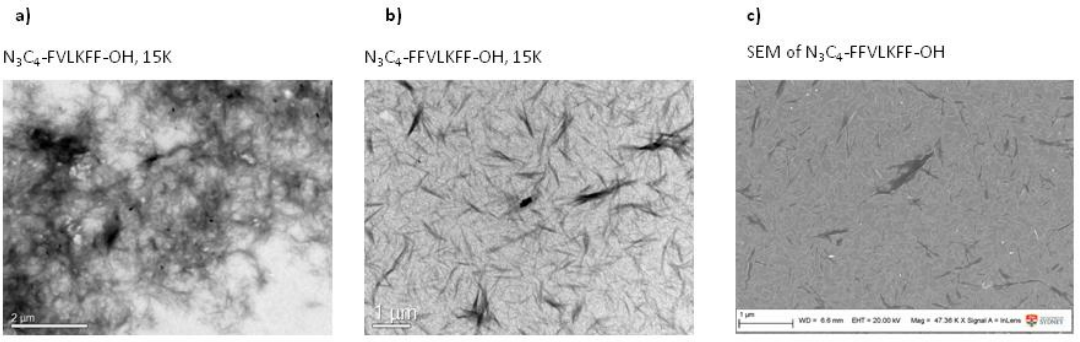

Figure 3: Typical TEM images of aggregates obtained from self-assembly of the conjugates (dried films of $1 \mathrm{wt} \%$ methanol solutions): a) TEM image of $\mathrm{N}_{3} \mathrm{C}_{4}$-FVLKFF-OH 1; b) TEM image of $\mathrm{N}_{3} \mathrm{C}_{4}$-FFVLKFF-OH 2; c) SEM image of $\mathrm{N}_{3} \mathrm{C}_{4}$-FFVLKFF-OH 2

The aggregation properties of the conjugates were investigated by FT-IR, CD, TEM and SAXS. FT-IR spectra show that FFVLKFF conjugates $8\left(P^{2} I P A A M 20\right)$ and 10 $\left(\right.$ PHEA $\left._{20}\right)$ and FVLKFF conjugates $7\left(\right.$ PNIPAAM $\left._{20}\right)$ and $9\left(\mathrm{PHEA}_{20}\right)$ are still able to form $\beta$-sheet assemblies (fig. 4). The FT-IR spectrum of FVLKFF PNIPAAM $_{20}$ conjugates 7 displays a slight shoulder at $1691 \mathrm{~cm}^{-1}$ (fig. $4 \mathrm{a}$, black arrow) which implies the presence of antiparallel $\beta$-sheets. The correspondent band around 1630 $\mathrm{cm}^{-1}$ from the parallel $\beta$-sheets is covered under the broad band from the PNIPAAM residue at $1652 \mathrm{~cm}^{-1}$. We conclude the broadness of the band for conjugate 7 around $1652 \mathrm{~cm}^{-1}$ and the appearance of the shoulder at $1691 \mathrm{~cm}^{-1}$ is evidence for to the presence of $\beta$-sheet structures which overlaps with the $C=O$ stretching band of the PNIPAAM part of the molecule. The FT-IR spectrum of the FVLKFF-PHEA 20 conjugate 9 (fig. $4 \mathrm{~b}$ ) shows a strong band around $1733 \mathrm{~cm}^{-1}$ resulting from the $\mathrm{C}=\mathrm{O}$ stretching band from the ester group of the PHEA side chain. At $1637 \mathrm{~cm}^{-1}$ and 1685 $\mathrm{cm}^{-1}$ appear two bands which are assigned to $\beta$-sheet structures ( $\beta$-sheet and antiparallel $\beta$-sheet respectively). From these results we assume that the attachment of $\mathrm{PHEA}_{20}$ does prevent the formation of strong fibre like networks but $\beta$-sheets are still formed. For FFVLKFF PNIPAAM 20 conjugates 8 two bands at $1550 \mathrm{~cm}^{-1}$ and $1652 \mathrm{~cm}^{-1}$ (fig. 4c) were observed resulting from the PNIPAAM residue. No shoulder around $1691 \mathrm{~cm}^{-1}$ could be obtained. But the broadness of the band at $1652 \mathrm{~cm}^{-1}$ for 8 is much more pronounced than the band for the pure PNIPAAM (fig. 4c, indicated with arrows). We conclude that the $\mathrm{C}=\mathrm{O}$ stretching band from PNIPAAM overlay the bands from parallel and antiparallel $\beta$-sheets. Further proof for the existence of $\beta$ sheet structures will be discussed below. The FT-IR spectrum of the FFKLVFF$\mathrm{PHEA}_{20}$ conjugate 10 shows also strong band around $1733 \mathrm{~cm}^{-1}$ from the ester group of the PHEA side chain. In addition a band $1687 \mathrm{~cm}^{-1}$ and $1644 \mathrm{~cm}^{-1}$ are obtained (fig. $4 \mathrm{~d}$, marked with arrows), which are assigned to antiparallel and respectively parallel $\beta$-sheets. 

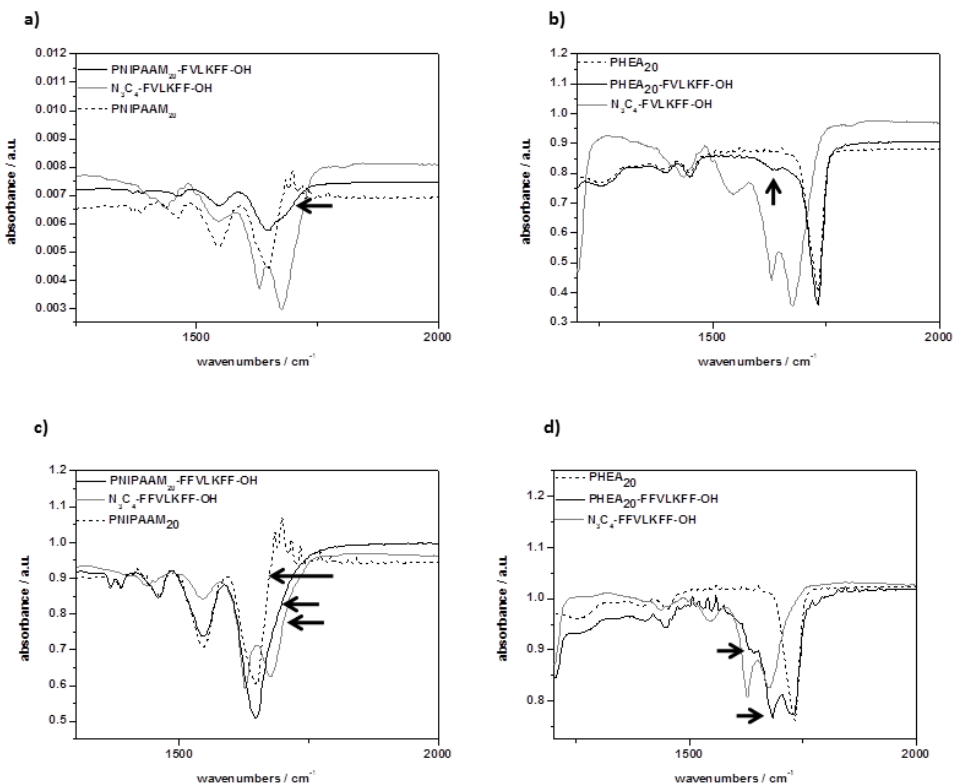

Figure 4: FT-IR spectra of conjugates 7 (a), 9 (b), 8 (c) and 10 (d) of dried films of $1 w t \%$ methanol solutions. Arrows indicate the relevant bands or changes in band shapes.

In order to investigate whether the FT-IR features are due to the conjugate $\mathbf{7}, \mathbf{8}, \mathbf{9}$ and 10 FT-IR mixing experiments were performed using peptide 1 and 2 and PNIPAAM $_{20}$ and PHEA $_{20}$ in a 1:1 mixture (SI, fig. 11 and fig. 12). For all four conjugates a clear red-shift of the amide bands is obtained, which is indicative of the formation of sheet-like aggregates. Moreover the mixture of FVLKFF $\mathbf{1}$ and PNIPAAM $_{20} 5$ displays a distinct shoulder in the related amide band around $1650 \mathrm{~cm}^{-1}$ indicating the presence of two different species in the solution with overlapping FT-IR bands. The FT-IR spectrum of the mixing experiment with FFVLKFF 2 and PNIPAAM 20 in a 1:1 mixture (SI, fig. 11b) shows a splitting of the band at $1652 \mathrm{~cm}^{-1}$ which is associated with the presence of two discrete compounds.

SAXS measurements on the FFVLKFF conjugates $8\left(\right.$ PNIPAAM $\left._{20}\right)$ and $10\left(\mathrm{PHEA}_{20}\right)$ and on the FVLKFF conjugates $7\left(\right.$ PNIPAAM $\left._{20}\right)$ and $9\left(\mathrm{PHEA}_{20}\right)$ in methanol (1wt\%) do not show any aggregation for conjugates $7,8,9$ and 10 under the conditions modelled by SAXS (fig. 5). In fact the SAXS data for conjugates the FFVLKFF conjugates 8 (PNIPAAM $\left.{ }_{20}\right)$ and $10\left(\right.$ PHEA $\left._{20}\right)$ can be modelled as Gaussian coil Comment [SD1]: lan, could you please check what I discussed here. I guess we could use some of your guess we could

Formatted: Font: Not Bold 
In addition no aggregation of the FVLKFFFor the FVLKFF conjugate-conjugate 7 could be detected. However SAXS experiments for FVLKVV-PHEA ${ }_{20} \mathbf{9}_{2}$ it was also possible to fit the data to a Gaussian coil model. However, the obtained radius, of gyration $(4.4 \mathrm{~nm})$ is larger than for the FFVLKFF conjugates. Gaussian coil form factor fitting was less successful for the SAXS data for conjugate 7 since the SAXS intensity exhibits an extended range (including low q) with a $\mathrm{q}^{-2}$ dependence. This indicates aggregation, consistent with the TEM images, and this intensity scaling is in fact expected for a sheet-like structure. Therefore, the SAXS data for conjugate 7 was fitted to a model of a homogeneous sheet (i.e. a planar object with extended

\begin{tabular}{l} 
Formatted: Font: Not Bold \\
Formatted: Font: Not Bold \\
Formatted: Font: Not Bold \\
Formatted: Font: Not Bold \\
Formatted: Font: Bold \\
\hline
\end{tabular}
lateral dimensions but finite thickness and a uniform electron density) of thickness 1 nm (30\% thickness polydispersity)-confirm the presence of aggregates which are modelled as sheet-like aggregates due to an observed $q^{-2}$ regime of intensity decay. The model of sheet-like structures is consistent with the TEM images, and data on related FFKLVFF-PEG conjugates: ${ }^{52}$ Fig. 5 shows representative profiles. For 9, form factor fitting was possible using a model of a homogeneous sheet of thickness $1 \mathrm{~nm}$ (30\% thickness polydispersity) and this model describes the intensity profile very well.

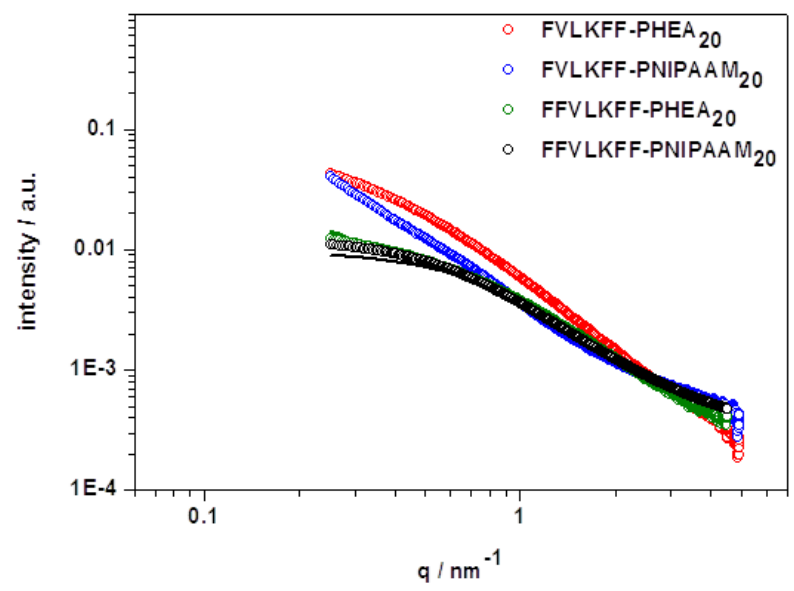

Figure 5: SAXS data for conjugates 7, 8, 9 and $\mathbf{1 0}$ (1 wt\% in methanol) The solid line through the data for conjugate $\mathbf{8}$ and $\mathbf{1 0}$ is the model form factor fit for the Gaussian coil structure described in the text.

Circular dichroism spectra were obtained from $1 \mathrm{wt} \%$ solutions of the conjugates in methanol. The CD spectra of PNIPAAM 20 conjugates 7 and 8 and PHEA $_{20}$ conjugates 9 and 10 (fig. $6 \mathrm{~b}$ and $6 \mathrm{c}$ ) in methanol display bands for $\beta$-sheet assemblies and confirm the FT-IR results. PNIPAAM 20 conjugates 7 and 8 display a negative 
maximum at $235 \mathrm{~nm}$ and a positive maximum at $220 \mathrm{~nm}$ (fig. 6a). The corresponding PHEA $_{20}$ conjugate 9 displays a minimum at $235 \mathrm{~nm}$ and a dominating maximum at $225 \mathrm{~nm}$, confirming the presence of $\beta$-sheets and aromatic stacking (fig. 6b). For conjugate 10 a broad minimum around $215-230 \mathrm{~nm}$ is observed as a result of a strong $\beta$-sheet component and a small band at $225 \mathrm{~nm}$ for the $\pi \pi$-stacking from the aromatic residues (fig. 6b). The observed red-shift of the minimum around $218 \mathrm{~nm}$ to $230 \mathrm{~nm}$ in all four spectra are induced by strong maximum from the $\mathrm{n}-\mathrm{m}^{*}$ aromatic interactions. $^{53}$
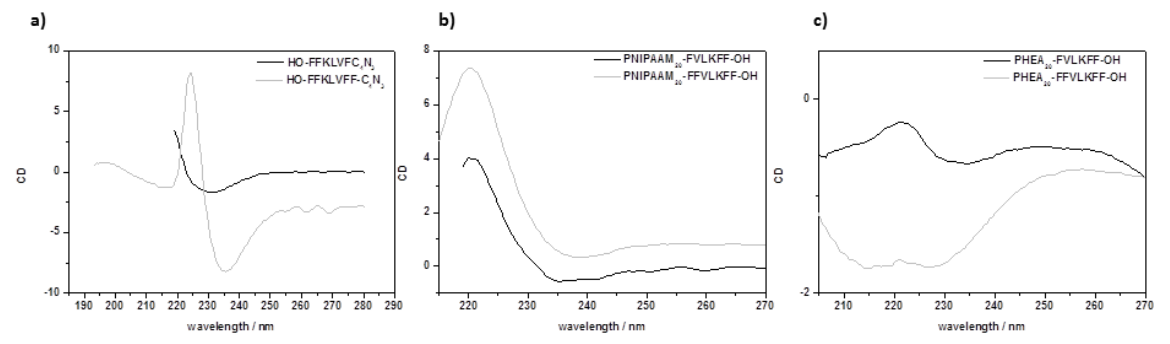

Figure 6: a) Circular dichroism spectrum of azide peptides 1 and 2 showing the characteristic negative and positive bands for $\beta$-sheet structures (1wt\% methanol); b) Circuar Dichroism spectrum of PNIPAAM 20 conjugates 7 and 8 (1wt\% methanol); c) Circuar Dichroism spectrum of PHEA $_{20}$ conjugates $\mathbf{9}$ and $\mathbf{1 0}$ (1wt\% methanol).

The CD spectra also support the conclusion by SAXS experiments that the peptide aggregation is disturbed by PNIPAAM $_{20}$. Indeed, FVLKFF conjugate 7 shows a red shift of the negative band from $230 \mathrm{~nm}$ to $235 \mathrm{~nm}$ which indicates a coiled structure for the PNIPAAM conjugate (fig. $7 \mathrm{a}){ }^{49}$
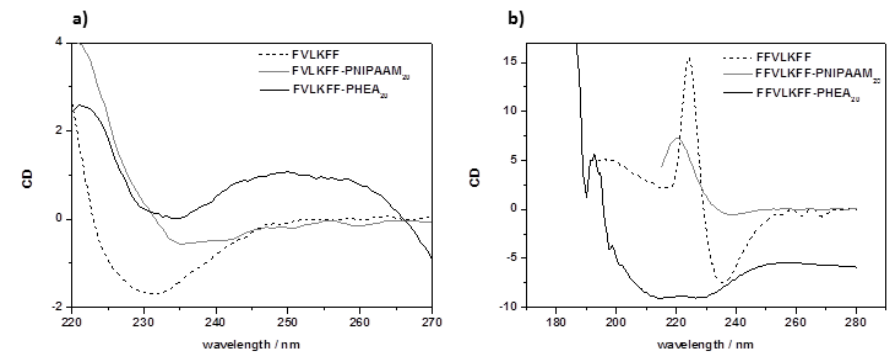

Figure 7: a) Circular Dichroism spectrum of FVLKFF 1 and correspondent PNIPAAM 20 and PHEA $_{20}$ conjugates 7 and 9 from 1wt\% methanol solution; b) Circular Dichroism spectrum of FFVLKFF 2 and correspondent PNIPAAM 20 and $\mathrm{PHEA}_{20}$ conjugates $\mathbf{8}$ and $\mathbf{1 0}$ from 1 wt $\%$ methanol solution. 
The CD spectrum of FFVLKFF conjugate $\mathbf{8}$ shows similar bands to the unconjugated peptide, indicating that the additional fourth phenylalanine residue strengthen the self-assembled structure, despite the presence of PNIPAAM. CD spectra of the PHEA conjugates 9 and 10, (fig. $7 \mathrm{a}$ and $7 \mathrm{~b}$ ) show typical $\beta$-sheet bands with a maximum at $195 \mathrm{~nm}$ and a minimum at $218 \mathrm{~nm}$. We rationalise these observations by the ability of the polymer chain to alter the aggregation of the peptide segment depending on the nature of the polymer conjugate. PNIPAAM chains interact with the peptide segment, possibly as it is less favoured by the solvent (methanol) and / or via $\mathrm{H}$-bond formation between the amide groups found in the peptide and the acrylamide repeating units. Such interactions do not completely prevent $\beta$-sheet assemblies, but strongly disturb aggregation in larger structures. The introduction of a fourth phenylalanine residue in the peptide segment strengthens the peptide assemblies and allows for the formation of larger aggregates, despite the presence of the PNIPAAM chain. The more polar PHEA chains have greater interactions with the solvent, and do not affect to the same extent $\beta$-sheet formation. The PHEA conjugate only partially prevents aggregation and favour dispersion in the solvent, thus leading to the formation of smaller structures. We have previously observed that conjugating PHEA to the $\beta$-sheet forming peptide $P_{11}-2$ prevents the assembly of the peptidic segment. ${ }^{33}$ This highlights the much stronger tendency of peptides $\mathbf{1}$ and $\mathbf{2}$ compared to peptide $P_{11}-2$ to aggregate into $\beta$-sheet-like structures and the importance of the functionality of the polymer to interfere with the peptide fibrillization.

TEM images of all four conjugates (fig. 8) reveal a small number of large aggregates, and confirm that attaching the polymers to peptide $\mathbf{1}$ and $\mathbf{2}$, although not extensively disturbing $\beta$-sheet formation, prevents the formation of strongly entangled networks.

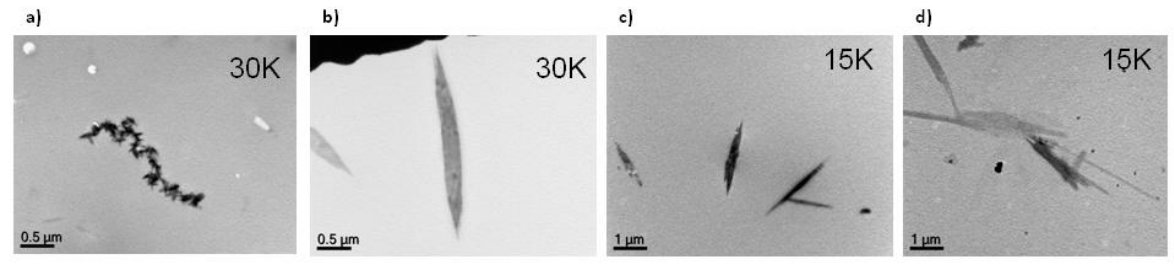

Figure 8: Typical TEM images of aggregates obtained from self-assembly of the conjugates (dried films of 1wt\% methanol solutions): a) FVLKFF PNIPAAM 20 , b) FFVLKFF PNIPAAM 20 , c) FVLKFF PHEA 20 and d) FFVLKFF PHEA 20 conjugates. Magnification is displayed on the top right corner of each image. 
TEM also confirmed that the self-assembly process of the conjugates into sheet-like aggregates is time and concentration dependent, an observation also made by CD spectroscopy.
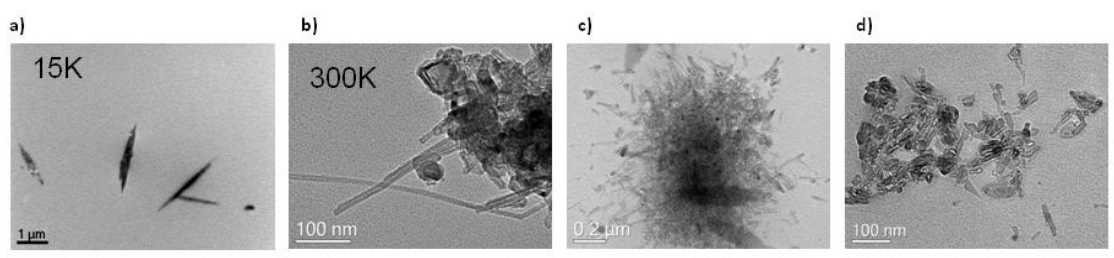

Figure 9: TEM images of self-assembled aggregates (dried films of $1 \mathrm{wt} \%$ methanol solution). a) freshly prepared PHEA $_{20}$-FVLKFF-OH 9 (1 wt\%); b) incubated PHEA 20 -FVLKFF-OH 9 (1 wt \%); c) incubated PHEA 20 FVLKFF-OH 9 (5 wt\%); incubated PHEA 20 -FFVLKFF-OH 10 (5 wt\%)

Indeed, TEM images from freshly prepared conjugate solutions (1 wt\% in methanol) show only small and thin aggregates (fig. 9a; SI, fig. 13-14, left). However, allowing the aggregates to self-assemble for $66 \mathrm{hrs}$ lead to an increased length ( 50-200 nm) and diameter $(\sim 10-20 \mathrm{~nm})$ in the range expected for amyloidal structures ${ }^{53}$ (fig. 9b; SI, fig. 13-14, right) indicating that the peptide part of the conjugate still has an impact on the overall properties of the conjugate and that the peptide properties become more pronounced after a period of time. However even after 66 hrs of incubation of the self-assembly process the entanglement of the aggregates are much less compared to the peptides $\mathbf{1}$ and $\mathbf{2}$ it selves. Increasing the concentration from 1 wt\% to 5 wt\% in PHEA $_{20}$ conjugates 9 (fig. 9c) and 10 (fig. 9d) led to the formation of larger and more structured aggregates. This gives the opportunity to influence the formation of the aggregates.

\section{Conclusion}

In conclusion, we have described a synthetic strategy and self-assembly studies for novel peptide-polymer conjugates, utilizing the manipulation of the self-assembly process via modified sequences from the $\beta$-amyloid peptide. Attaching short polymers of different functionality, PNIPAAM 20 and $\mathrm{PHEA}_{20}$, to these peptide sequences disturbs their strong fibrillisation properties and offers some degree of control over their aggregation. Our findings point out that a sensible choice in the nature of polymer conjugate in relation to the solvent may allow control over the selfassembly process. This approach is a promising way to address the challenging task to control the strong aggregation of $\beta$-sheet forming peptides and their use for controlled synthesis of functionalised supramolecular polymeric structures. 


\section{Acknowledgements}

The ARC (Discovery Program DP1096651) and the EPSRC (EP/F048114/1, EP/G026203/1 and EP/G067538/1) is gratefully acknowledged for financial support. The authors thank Ashkan Dehsorkhi for assistance with the CD measurements.

\section{Supporting Information}

Supplementary Information (SI) available: Nuclear Magnetic Resonance (NMR), Electro Spray Ionisiation Mass Spectrometry (ESI), High Resolution Mass Spectrometry (High Res MS), Fourier Transformation Infrared Spectroscopy (FTIR), Size Exclusion Chromatography (SEC), Transmission Electron Microscopy (TEM), Circular Dichroism (CD).

\section{References}

(1) Klok, H. A. J. Polym. Sci. A 2005, 43, 1-17.

(2) Drotleff, S.; Lungwitz, U.; Breunig, M.; Dennis, A.; Blunk, T.; Tessmar, J.; Göpferich, A. European Journal of Pharmaceutics and Biopharmaceutics 2004, 58, 385-407.

(3) Klok, H.-A. Macromolecules 2009, 42, 7990-8000.

(4) Rösler, A.; Klok, H. A.; Hamley, I. W.; Castelletto, V.; Mykhaylyk, O. O. Biomacromolecules 2003, 4, 859-863.

(5) Hamley, I. W. Angew. Chem. Int. Ed. 2007, 46, 8128-8147.

(6) Hartgerink, J. D.; Beniash, E.; Stupp, S. I. Science 2001, 294, 1684-1688.

(7) Reches, M.; Gazit, E. Science 2003, 300, 625-627.

(8) Yang, Y. L.; Khoe, U.; Wang, X. M.; Horii, A.; Yokoi, H.; Zhang, S. G. Nano Today 2009, 4, 193-210.

(9) Ulijn, R. V.; Smith, A. M. Chem. Soc. Rev. 2007, 37, 664-675.

(10) Zelzer, M.; Ulijn, R. V. Chem. Soc. Rev. 2010, 39, 3351-3357.

(11) Gauthier, M. A.; Klok, H. A. Chem. Comm. 2008, 2591-2611.

(12) Aggeli, A.; Bell, M.; Boden, N.; Keen, J. N.; Knowles, P. F.; McLeish, T. C. B.; Pitkeathly, M.; Radford, S. E. Nature 1997, 386, 259-262.

(13) Dobson, C. M. Nature 2003, 426, 884.

(14) Goedert, M.; Spillantini, M. G. Science 2006, 314, 777.

(15) McLean, P. J.; Kawamata, H.; Hyman, B. T. Neuroscience 2001, 104, 901-

(16) Kahn, S. E.; Andrikopoulos, S.; Verchere, C. B. Diabetes 1999, 48, 241-253.

(17) Chimon, S.; Shaibat, M. A.; Jones, C. R.; Calero, D. C.; Aizezi, B.; Ishii, Y. Nature Structural and Molecular Biology 2007, 14, (12), 1157-1164.

(18) Tjernberg, L. O.; Lilliehook, C.; Callaway, D. J. E.; Naslund, J.; Hahne, S.; J., T.; Terenius, L.; Nordtsedt, C. J. Biol. Chem. 1997, 272, 12601.

(19) Krysmann, M. J.; Castelletto, V.; Hamley, I. W. Soft Matter 2007, 3, 14011406.

(20) Krysmann, M. J.; Castelletto, V.; Kelarakis, A.; Hamley, I. W.; Hule, R. A.; Pochan, D. J. Biochemistry 2008, 47, 4597-4605. 
(21) Dehn, S.; Chapman, R.; Jolliffe, K.; Perrier, S. Polym. Rev. 2011, 51, 214

(22) Canalle, L. A.; Loewik, D. W. P. M.; Van Hest, J. C. M. Chem. Soc. Rev. 2010, 39, 329-353.

(23) Yu, M.; Nowak, A. P.; Deming, T. J.; Pochan, D. J. J. Am. Chem. Soc. 1999, $121,12210-12211$.

(24) Kotharangannagari, V. K.; Sánchez-Ferrer, A.; Ruokolainen, J.; Mezzenga, R. Macromolecules 2012, 45, 1982-1990.

(25) Hamley, I. W.; Krysmann, M. J. Langmuir 2008, 24, 8210-8214.

(26) Johnson, J. C.; Wanasekara, N. D.; Korley, L. T. J. Biomacromolecules 2012, 13, 1279-1286.

(27) Radu, L. C.; Yang, J.; Kopecek, J. Macromolecular Bioscience 2009, 9, 36-

44.

(28) Shaytan, A. K.; Schillinger, E.-K.; Khalatur, P. G.; Mena-Osteritz, E.; Hentschel, J.; Börner, H. G.; Bäuerle, P.; Khokhlov, A. R. ACS Nano 2011, 5, (9), 6894-6909.

(29) Adams, D. J.; Atkins, D.; Cooper, A. I.; Furzeland, S.; Trewin, A.; Young, I. Biomacromolecules 2008, 9, 2997-3003.

(30) Tzokova, N.; Fernyhough, C. M.; Butler, M. F.; Armes, S. P.; Ryan, A. J.; Topham, P. D.; Adams, D. J. Langmuir 2009, 25, (18), 11082-11089.

(31) Burkoth, T. S.; Benzinger, T. L. S.; Jones, D. N. M.; Hallenga, K.; Meredith, S. C.; Lynn, D. G. J. Am. Chem. Soc. 1998, 120, 7655-7656.

(32) Rathore, O.; Winningham, M. J.; Sogah, D. Y. J. Polym. Sci. A 2000, 38, 352-

366.

(33) Kakwere, H.; Payne, R. J.; Jolliffe, K. A.; Perrier, S. Soft Matter 2011, 7, 3754-3757.

(34) Chapman, R.; Jolliffe, K.; Perrier, S. Polym. Chem. 2011, 2, 7977-7979.

(35) Hentschel, J.; Börner, H. G. Macromolecular Bioscience 2009, 9, 187-194.

(36) Börner, H. G. Progress in Polymer Science 2009, 34, 811-851.

(37) Harris, J. M.; Chess, R. B. Nature Reviews Drug Discovery 2003, 2, 214-221.

(38) Castelletto, V.; Newby, G. E.; Zhu, Z.; Hamley, I. W. Langmuir 2010, 26, (12), 9986-9996.

(39) Burkoth, T. S.; Benzinger, T. L. S.; Urban, V.; Lynn, D. G.; Meredith, S. C.; Thiyagarjan, P. J. Am. Chem. Soc. 1999, 121, 7429-7430.

(40) Srinivasan, R.; Tan, L. P.; Wu, H.; Yang, P. Y.; Kalesh, K. A.; Yao, S. Q. Org. Biomol. Chem. 2009, 7, (9), 1821-1828.

(41) Konkolewicz, D.; Gray-Weale, A.; Perrier, S. J. Am. Chem. Soc. 2009, 131, 19075-19077.

(42) Chapman, R.; Jolliffe, K. A.; Perrier, S. Aus. J. Chem. 2010, 63, 1169-1172.

(43) Poon, C. K.; Chapman, R.; Jolliffe, K. A.; Perrier, S. Polym. Chem. 2012, 3, 1820-1826.

(44) Moad, G.; Rizzardo, E.; Thang, S. H. Aus. J. Chem. 2009, 62, 1402-1472.

(45) Perrier, S.; Takolpuckdee, P. J. Polym. Sci. A 2005, 43.

(46) Semsarilar, M.; Perrier, S. Nature Chem. 2010, 2, 811-820.

(47) Kakwere, H.; Chun, C. K. Y.; Jolliffe, K. A.; Payne, R. J.; Perrier, S. Chem. Comm. 2010, 46, 2188-2190.

(48) Haris, P.; Chapman, D. Biopolymers 1995, 37, 251-263.

(49) Hamley, I. W.; Nutt, D. R.; Brown, G. D.; Miravet, J. F.; Escuder, B.; Rodriguez-Liansola, F. J. Phys. Chem. B 2010, 114, (2), 940-951.

(50) Kelly, S. M.; Jess, T. J.; Price, N. C. Biochimica et Biophysica Acta 2005, 1751, 119-139.

(51) Whitten, D. G. Acc. Chem. Res. 1993, 26, 502-509.

(52) Castelletto, V.; Cheng, G.; Furzeland, S.; Atkins, D.; Hamley, I. W. Biomacromolecules submitted, submitted. 
(53) Castelletto, V.; Hamley, I. W.; Harris, P. J. F. Biophysical Chemistry 2008, 138, 29-35. 